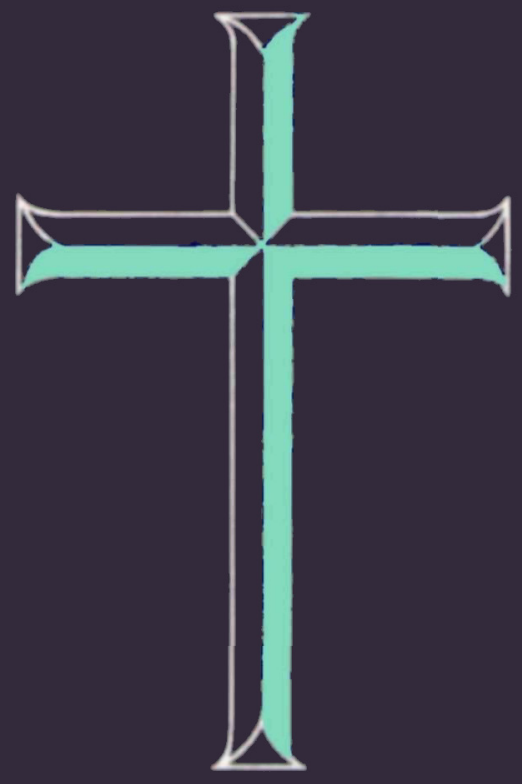

SCOTTISH JOURNAL $g^{\circ}$

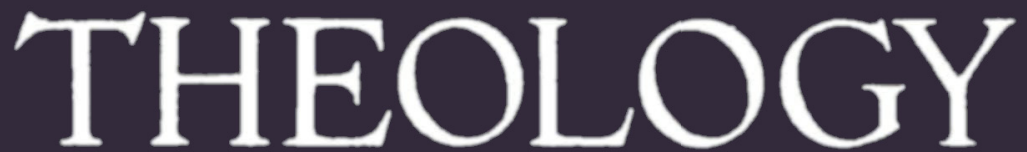
Vol. 10, No. 3
$6 / 6$
September 1957 


\section{HODDER AND STOUGHTON}

announce for publication on October 24 the new book by

Professor T. F. Torrance M.B.E., D.D., D.Th.

\section{WHEN CHRIST COMES AND COMES AGAIN}

Professor Torrance, the distinguished Scottish theologian, has presented in a simple, stimulating book, the urgent message of the church between the two Advents of Christ. This is evangelism that is more concerned with presenting Christ than with arousing human decisions, in the belief that the compelling power of the Gospel itself may make its appeal directly, unhindered by the artificial representation of the popular evangelist. This is a book from the heart of the faith for all those who seek to understand and know the Gospel, as well as all those engaged in Tell Scotland campaigns and similar Christian enterprises.

$12 / 6$ net

Also in the new Hodder and Stoughton religious list

\section{Professor David Talbot Rice's THE BEGINNINGS OF CHRISTIAN ART}

(magnificently illustrated)

Designed to become the standard work.

42/-net

Professor Gordon Rupp's

SIX MAKERS OF ENGLISH RELIGION 1500-I700

$A$ vivid and illuminating picture of six dynamic men and their immortal work: Tyndale and the English Bible, Cranmer and the Prayer Book, John Foxe and the Book of Martyrs, John Bunyan and Pilgrim's Progress, John Milton and Paradise Lost, Isaac Watts and his Hymns.

$8 / 6$ net

\section{Dr. Raynor C. Johnson \\ NURSLINGS OF IMMORTALITY}

"It is a stimulating book which reflects the kind of creative intelligence for which imagination is another name, and blends scientific thought and poetic insight in an unusual way."

Times Literary Supplement

$25 /$ - net

Please write for full particulars to

HODDER AND STOUGHTON LTD., Warwick Square, E.C.4 


\title{
THE GOSPEL ACCORDING TO ST JOHN
}

\section{K. BARRETT}

3os. net

The first cheap edition of Dr Barrett's commentary which all the reviewers acclaimed as a book of the first importance.

\section{NEW TESTAMENT BACKGROUND: SELEGTED DOCUMENTS}

\author{
C. K. BARRETT
}

2rs. net

'A book of immense value'

Expository Times

\section{RELATIONS BETWEEN ANGLIGAN AND PRESBYTERIAN GHURCHES}

A JOINT REPORT

38. 6 d.

\section{HOW SHALL THEY HEAR?}

GORDON W. IRESON

9s. 6d, net

The first book to be published in the Priest's Library is a book on preaching by a well-known preacher. Canon Ireson's insight into the problems of preachers and also into the minds of the congregation is remarkable.

\section{GHRIST AND HIS GHURCH}

\section{ANDERS NYGREN}

ros 6d, net

'This is partly a work of New Testament exegesis, partly an elaboration of an ecumenical theology . . . . a book to be read for the detail of the argument.'

Manchester Guardian

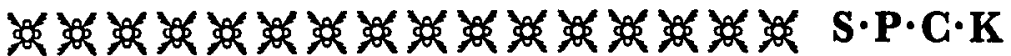




\section{BINDING}

We shall be glad to undertake the binding of separate parts of Scottish Journal of Theology into complete volumes at a cost of $14 \mathrm{~s}$. $6 \mathrm{~d}$. per volume.

Binding cases can be supplied separately at 3s. 3d. each.

Please send enquiries to Binding Department

OLIVER AND BOYD

Tweeddale Court, Edinburgh 1 


\title{
The Oxford Dictionary of the Christian Church
}

\author{
Edited by F. L. CROSS \\ Lady Margaret Professor of Divinity in the \\ University of Oxford and Canon of Christ Church
}

This comprehensive one-volume work will take its place among the Oxford reference books beside the Companions-to English Literature, to Music, etc.- -and the Oxford Classical Dictionary.

Its aim is to provide factual information on every aspect of Christianity, especially in its historical development. It contains an alphabetical sequence of well over 6,000 entries or articles ranging from a few lines to about 2,500 words in length, and, appended to the relevant articles, nearly 4,500 concise but important bibliographies.

Biography (Fathers, Saints, Popes, reformers, writers, etc.) naturally accounts for many entries, but others include Christian bodies (local churches, denominations, orders, etc.) doctrine, liturgy, canon law, institutions and customs, asceticism and devotion, places with special Christian associations, councils, documents, and important individual writings (e.g. Cerne, Book of; Scottish Confession).

Biblical subjects are covered briefly (owing to the existence of other reference books in that field); all post-Biblical periods, and all Christian traditions, Eastern and Western, Catholic and Protestant, European and extra-European, are included, with, however, most stress on what the modern Western reader is most likely to require.

The comprehensiveness, balance, and scholarly authority of this volume, together with the bibliographical information included, make it of unique value not only to the scholar but to the educated reader generally both in English-speaking countries and throughout the world.

A detailed prospectus is available.

Royal 8vo, I,512 pages

Price in U.K. 70 s. net

\section{OXFORD UNIVERSITY PRESS}




\title{
SCOTTISH JOURNAL
} of

\section{THEOLOGY}

Vol. 10, No. 3

September 1957

EDITORS:

Rev. Professor T. F. TORRANCE

Rev. Professor J. K. S. REID

\author{
OLIVER \& BOYD LTD. \\ RDINBURGH : TWEEDDALE COURT \\ LONDON: 39A WELBECK STREET, W.I.
}




\title{
SCOTTISH JOURNAL OF THEOLOGY
}

\author{
Published Quarterly
}

\author{
Editors: \\ Rev. Prop. T. F. Torrance, M.B.E., D.D., D.Theol., \\ 21 South Oswald Road, Edinburgh, 9 (Telephone 46114) \\ Rev. Prof. J. K. S. ReID, D.D., \\ 44 Headingley Mount, Leeds, 6 (Telephone 56853) \\ Consulting Editors: \\ Rev. Pringipal J. H. S. Burleigh, D.D., B.LrtT. \\ Chairman of Directors \\ Rev. Prof. David Gairns, D.D. \\ Rev. Prof. N. W. Porteous, D.D. \\ Directors: \\ The above-named together with \\ Rev. Prop. E. P. Dickie, M.C., D.D. \\ Rev. Prop. G. S. Hendry, D.D. \\ Rev. J. Heron, B.D., S.T.M. \\ Rev. A. MaCosh, M.A., S.T.M. \\ Rev. J. A. McFadden, B.D. \\ Rev. J. W. Stevenson, M.A. \\ Rev. R. S. WAllace, M.A., B.Sc. \\ Rev. T. M. Murchison, M.A., Secretary
}

CONTRIBUTIONS are invited from members of all branches of the Christian Church.

EDITORIAL CORRESPONDENCE-MSS and Books for review should be sent to one of the Editors.

BUSINESS CORRESPONDENCE should be sent to the Registered Office. PRICE: Six Shillings and Sixpence per copy, post free.

ANNUAL SUBSCRIPTION: Twenty-two Shillings and Sixpence, post free.

PUBLIBHED BY OLIVER AND BOYD FOR SCOTTISH JOURNAL OF THEOLOOY LTD.

Registered Office : TWEEDDALE COURT, EDINBURGH, I 


\section{CONTENTS}

Three Critical Issues in Tilligh's Philosophical Theology, by the Rev. Professor Nels F. S. Ferré, D.D., D.Th., AndoverNewton, Mass.

The Relevance of Kierkegaard to the Demythologising ConTroversy, by the Rev. J. Heywood Thomas, B.A., B.D., S.T.M., Oxford

Theological Thinking, by Dr R. A. Markus, Liverpool

Didactic Kerygma in the Synoptic Gospels, by the Rev. John J. Vincent, B.D., S.T.M., Manchester

The Confession 'Jesus is God' in the New Testament, by the Rev. A. W. Wainwright, B.A., M.A., Birmingham

Boox Reviews:

Hendrik Kraemer: Religion and the Christian Faith, by the Rev. J. R. Fleming, Singapore

S. Mowinckel: He That Cometh, translated by G. W. Anderson, by the Rev. Dr A. J. B. Higgins, Leeds

C. K. Barrett: The New Testament Background, by the Rev. Dr R. McL. Wilson, St. Andrews

James M. Robinson: The Problem of History in Mark, by the Rev. Dr William Neil, Nottingham

Amos N. Wilder: New Testament Faith for Today, by the Rev. D. M. G. Stalker, Edinburgh

John Marsh: A Year with the Bible, by the Rev. D. M. G. Stalker, Edinburgh

John Bright: Early Israel in Recent History Writing, by the Rev. Principal Norman H. Snaith, Leeds

Harry Blamires: The Faith and Modern Error, by the Rev. Dr James Brown, Colmonell

Abba Hillel Silver: Where Judaism Differs, by the Rev. Nahum Levison, Edinburgh

Arthur F. Smethurst: Modern Science and Christian Beliefs, by the Rev. David F. S. Dick, Edinburgh

Heinrich Schlier: Die Zeit der Kirche, by the Rev. Professor Allan Barr, Edinburgh

Friedrich Brunstäd: Theologie der lutherischen Bekenntnisschriften, by the Rev. D. Ritschl, Edinburgh 
Thomas M. Donn: The Sacrament of Reconciliation, by the Rev. Dr George S. Gunn, Edinburgh

Adam Fox: Plato and the Christians, by Professor J. A. Davidson, Leeds

Myself and My Creed, edit. by E. H. Hayes and F. S. Poplam, by Mr A. E. Elms, Leeds

Edgar P. Dickie: A Safe Stronghold, by Mr A. E. Elms, Leeds

Ronald Selby Wright: The Kirk of the Canongate, by the Rev. A. I. Dunlop, Edinburgh

W. Montgomery Watt: Muhammad in Medina by the Rev. J. M. Ritchic, Aden

J. Windrow Sweetman: Islam and Christian Theology, by the Rev. J. M. Ritchie, Aden

\section{IN THIS ISSUE}

Articles on Tillich's Theology

Demythologising

Theological Thinking

the Kerygma

The Biblical Study is on the Confession: Jesus is God

Among the reviews are works by $\mathrm{H}$. Kraemer

S. Mowinckel

and books on the New Testament Background

the Problem of Christ

Early Israel

Faith and Error

Judaism and Christianity 